\title{
Interleukins Affect Equine Endometrial Cell Function: Modulatory Action of Ovarian Steroids
}

\author{
Anna Z. Szóstek, ${ }^{1}$ Antonio M. Galvão, ${ }^{1}$ Takuo Hojo, ${ }^{1}$ \\ Kiyoshi Okuda, ${ }^{2}$ and Dariusz J. Skarzynski ${ }^{1}$ \\ ${ }^{1}$ Department of Reproductive Immunology and Pathology, Institute of Animal Reproduction and Food Research, \\ 10-748 Olsztyn, Poland \\ ${ }^{2}$ Laboratory of Reproductive Endocrinology Graduate School of Natural Science and Technology, \\ Okayama University, 700-8530 Okayama, Japan
}

Correspondence should be addressed to Anna Z.Szóstek; a.szostek@pan.olsztyn.pl

Received 19 December 2013; Accepted 14 January 2014; Published 27 February 2014

Academic Editor: Graça Ferreira-Dias

Copyright (C) 2014 Anna Z. Szóstek et al. This is an open access article distributed under the Creative Commons Attribution License, which permits unrestricted use, distribution, and reproduction in any medium, provided the original work is properly cited.

\begin{abstract}
The aim of the present study was to investigate the interaction between ovarian steroids, interleukins and prostaglandins (PG) in equine epithelial and stromal cells in vitro. In Experiment 1 , cells were exposed to IL- $1 \alpha(10 \mathrm{ng} / \mathrm{mL}), \mathrm{IL}-1 \beta$ ( $10 \mathrm{ng} / \mathrm{mL})$ or IL$6(10 \mathrm{ng} / \mathrm{mL})$ for $24 \mathrm{~h}$ and cell proliferation was determined using MTT. In Experiment 2, cells were exposed to progesterone $\left(\mathrm{P}_{4} ; 10^{-7} \mathrm{M}\right) ; 17-\beta$ estradiol $\left(\mathrm{E}_{2} ; 10^{-9} \mathrm{M}\right)$ or $\mathrm{P}_{4}+\mathrm{E}_{2}$ for $24 \mathrm{~h}$ and later medium was replaced with a fresh one treated with IL-1 $\alpha$, IL-1 $\beta$ or IL-6 $\left(10 \mathrm{ng} / \mathrm{mL}\right.$, each) for $24 \mathrm{~h}$. The oxytocin (OT; $\left.10^{-7} \mathrm{M}\right)$ was used as a positive control. In Experiment 3, cells were exposed to $\mathrm{P}_{4}\left(10^{-7} \mathrm{M}\right), \mathrm{E}_{2}\left(10^{-9} \mathrm{M}\right)$ or $\mathrm{P}_{4}+\mathrm{E}_{2}$ for $24 \mathrm{~h}$ and the IL receptor mRNAs transcription was determined using Real-time PCR. Prostaglandins concentration was determined using the direct enzyme immunoassay (EIA) method. Our findings reveal a functional linking between ovarian steroids and IL-stimulated PG secretion by equine endometrial cells. This interaction could be one of the mechanisms responsible for endometrial local orchestrating events during the estrous cycle and early pregnancy.
\end{abstract}

\section{Introduction}

Endometrium is a complex tissue, which consists of different cell types. The overriding purpose of endometrial cyclicity is the preparation for embryo implantation. Interactions between prostaglandins (PG) and ovarian steroids play a crucial role in diverse complex processes in several species. The ovarian steroids affect the morphological and functional state of the endometrium. The 17- $\beta$ estradiol $\left(\mathrm{E}_{2}\right)$ regulates sexual behavior, enhances uterine motility, and promotes secretory activity of the entire reproductive tract. In turn, progesterone $\left(\mathrm{P}_{4}\right)$ affects endometrial secretion, promotes the pregnancy maintenance, and inhibits gonadotropin-releasing hormone $(\mathrm{GnRH})$ secretion and reproductive behavior. Ovarian steroids have also been demonstrated to affect PG during the estrous cycle in vivo in the mare $[1,2]$. Ovarian steroid-stimulated PG secretion by equine endometrial cells was recently evidenced in vitro $[3,4]$. Prostaglandins act locally, modulating endometrial biological processes, such as cell proliferation, angiogenesis, embryo implantation, or peripherally on corpus luteum $(\mathrm{CL})$ maintenance and luteolysis [5-10].

Interleukins (ILs) are secreted by numerous immune cells, acting mostly in an auto/paracrine manner. Interleukins such as IL- $1 \alpha$ and IL- $1 \beta$ or IL- 6 are known to participate in the regulation of endometrial PG synthesis in many species [11-15]. There are two types of IL agonists (IL-1 $\alpha$ and IL-1 $\beta$ ) and both of them determine biological responses via specific receptor. Although there are two types of IL-1 receptors (IL-1RI and IL-1RII), only IL-1RI transduces IL-1 signaling response [16]. Interleukin 6 is a pleiotropic cytokine, which is produced by different immune and nonimmune cell types [17]. Interleukin 6 binds to a low-affinity subunit called gp 80 or IL-6R $\alpha$ on the surface of target cells, promoting tIL-6/IL$6 \mathrm{R}$ alpha complex recruitment of signal-transducing subunits called gp130 or IL-6R $\beta$ [17]. 
In our study, we hypothesized that there is a functional link between IL, PG, and ovarian steroids, where ovarian steroids modulate PG secretion stimulated by IL. To clarify the interaction of those molecules we investigated: (i) the IL influence on PG production and epithelial and stromal cell proliferation, (ii) the modulatory effect of ovarian steroids on IL-stimulated production of PG, and (iii) the effect of ovarian steroids on IL receptors mRNAs transcription.

\section{Materials and Methods}

2.1. Animals and Endometrial Tissue Collection. Uteri $(n=$ 10) from cyclic mares at the early luteal phase of estrous cycle were collected postmortem, from April until the end of July at a local abattoir. The mares were healthy as stated by the official governmental veterinary inspection. The estrous cycle phases were identified based on $\mathrm{P}_{4}$ and $\mathrm{E}_{2}$ analysis in blood serum and an ovary macroscopic observation $[18,19]$. The early luteal phase is characterized by the corpora hemorrhagica presence with a plasma concentration of $\mathrm{P}_{4}>1 \mathrm{ng} / \mathrm{mL}$. At the mid luteal phase, the developed CL is associated with follicles $15-20 \mathrm{~mm}$ in diameter and $\mathrm{P}_{4}>6 \mathrm{ng} / \mathrm{mL}$. At the late luteal phase, a regressing $\mathrm{CL}$ is present, together with follicles $30-35 \mathrm{~mm}$ in diameter and a concentration of $\mathrm{P}_{4}$ from $1-2.5 \mathrm{ng} / \mathrm{mL}$. The follicular phase is characterized by an active CL absence and a follicle with various sizes presence but always $>35 \mathrm{~mm}$ diameter, with a concentration of $\mathrm{P}_{4}<$ $1 \mathrm{ng} / \mathrm{mL}[18,19]$. Moreover, the phases were differentiated, since serum $\mathrm{E}_{2}$ was present in basal concentration in luteal phase (around 2 to $10 \mathrm{pg} / \mathrm{mL}$ ), but it reaches values above $20 \mathrm{pg} / \mathrm{mL}$ in the follicular phase [20]. The entire uterus was collected within $5 \mathrm{~min}$ of an animal's death, placed in sterile, incomplete $\left(\mathrm{Ca}^{2+}\right.$ and $\mathrm{Mg}^{2+}$ free) Hank's balanced salt solution (HBSS) supplemented with gentamicin $(20 \mu \mathrm{g} / \mathrm{mL}$; Sigma-Aldrich, Madison, USA, \#G1272) and 0.1\% bovine serum albumin (BSA; Sigma-Aldrich, Madison, USA, \#A9056), kept on ice, and transported quickly to laboratory. Small pieces of endometrium from each uterus were placed in buffered 4\% paraformaldehyde for histological analysis [18], for further classification according to the scoring system developed by Kenney [21]. Only cells derived from category I endometria of Kenney [21] classification were used in the present study. Animal treatment procedures and tissue collection were approved by the Local Animal Care and Use Committee in Olsztyn, Poland (Agreements No. 51/2011).

2.2. Epithelial and Stromal Cells Isolation and Culture. A total of 10 uteri from mares in early luteal phase of the estrous cycle were used. The equine epithelial and stromal cells were isolated following the methodology recently described [22]. Cells were cultured at $38^{\circ} \mathrm{C}$ in a humidified atmosphere of $5 \% \mathrm{CO}_{2}$. The culture medium was Dulbecco's modified Eagle's medium/nutrient F-12 Ham (DMEM/Ham's F-12; Sigma-Aldrich, Madison, USA; D8900) supplemented with $10 \%$ fetal calf serum (FCS; Sigma-Aldrich, Madison, USA; \#C6278) and antibiotic and antimycotic solution (SigmaAldrich, Madison, USA; \#A5955); it was changed every 2 to 3 days. After reaching 90 to $95 \%$ confluence (5 or 7 days of the incubation of stromal or epithelial cells, resp.), cells were trypsinized [22].Further, cells were seeded at a density of $5 \times 10^{5}$ viable cells $/ \mathrm{mL}$ for epithelial cells and $2 \times 10^{5}$ viable cells $/ \mathrm{mL}$ of stromal cells in 24 or 96 -well plates, regarding the experiment. Both cell types viability were over $90 \%$.The cell culture homogeneity was evaluated using immunofluorescent staining for epithelial and stromal cell specific markers (cytokeratin, vimentin, resp.) as described before [22]. The epithelial and stromal cell homogeneity was around $97 \%$.

\subsection{Experimental Procedures}

2.3.1. Experiment 1: The Effect of Interleukin on Epithelial and Stromal Cell Proliferation. Stromal $(n=5)$ and epithelial $(n=5)$ cells derived from passage I were placed in a 96well plate. After reaching $50 \%$ of confluence, the medium was replaced with fresh DMEM without phenol red supplemented with $0.1 \%$ BSA and antibiotics and antimycotic solution. Then, cells were incubated with vehicle or with IL- $1 \alpha$, IL$1 \beta$, or IL-6 $(10 \mathrm{ng} / \mathrm{mL}$ each). After $24 \mathrm{~h}$, cells proliferation was measured by MTT (3-[4,5-dimethylthiazol-2-yl]2,5-diphenyltetrazolium bromide) method using TOX-1 Kit (Sigma-Aldrich, Madison, USA, \#7H258), according to the manufacturer's instructions.

\subsubsection{Experiment 2: The Effect of Ovarian Steroids on} Cytokine-Stimulated PG Production by Endometrial Cells. Epithelial (Figure 1(a); $n=5$ ) and stromal (Figure 1(b); $n=5$ ) cells derived from passage I were placed in a 24 -well plate in the culture medium DMEM/Ham's F-12 supplemented with $10 \%$ FCS and antibiotic and antimycotic solution. Again, when cells reached $90 \%$ of confluence, the medium was replaced with fresh DMEM without phenol red (SigmaAldrich, Madison, USA; D\#2960) supplemented with $0.1 \%$ BSA and antibiotics and antimycotic solution. The epithelial and stromal cells were incubated with vehicle or with $\mathrm{P}_{4}$ $\left(10^{-7} \mathrm{M}\right), \mathrm{E}_{2}\left(10^{-9} \mathrm{M}\right)$ or $\mathrm{P}_{4}+\mathrm{E}_{2}\left(10^{-7} \mathrm{M} / 10^{-9} \mathrm{M}\right)$ added to the culture medium for $24 \mathrm{~h}$. The doses for ovarian steroids were determined based on our former work [4]. Further on, the medium was replaced with fresh DMEM without phenol red supplemented with $0.1 \%$ BSA and antibiotics and antimycotic solution. Epithelial and stromal cells were then incubated with IL- $1 \alpha / \mathrm{IL}-1 \beta / \mathrm{IL}-6(10 \mathrm{ng} / \mathrm{mL})$ for the next $24 \mathrm{~h}$. The oxytocin (OT; $\left.10^{-7} \mathrm{M}\right)$ was used as a positive control. Then, conditioned media were collected into tubes with $5 \mu \mathrm{L}$ EDTA, 1\% acetylsalicylic acid solution (Sigma-Aldrich, Madison, USA, \#A2093), and frozen at $-20^{\circ} \mathrm{C}$ until further PG measurement. The total volume of $250 \mu \mathrm{L}$ TRI Reagent (Sigma-Aldrich, Madison, USA, \#T9424) was added to each well containing cells for single-step DNA isolation. Cells from four wells were then polled. Deoxyribonucleic acid was isolated according to TRI Reagent manufacturer procedure. Deoxyribonucleic acid content was used to standardize the results.

2.3.3. Experiment 3: The Effect of Ovarian Steroids on IL Receptor mRNAs Transcription in Epithelial and Stromal Cells 


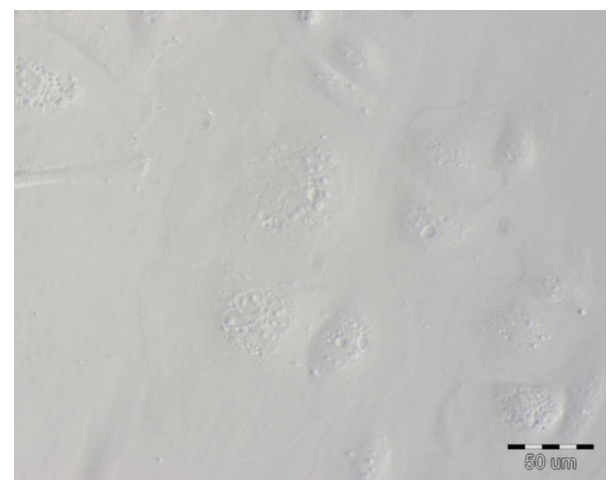

(a)

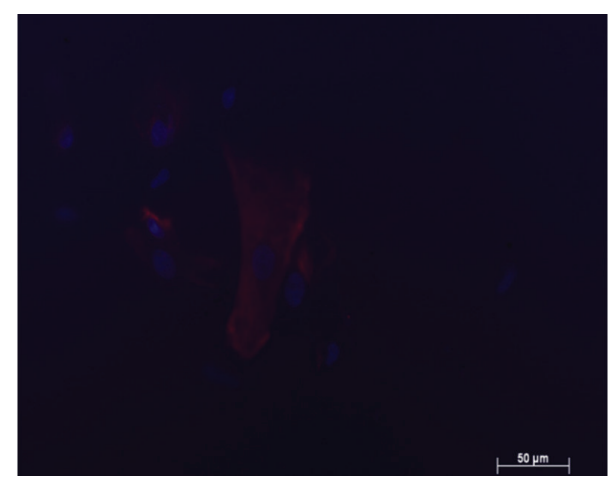

(c)

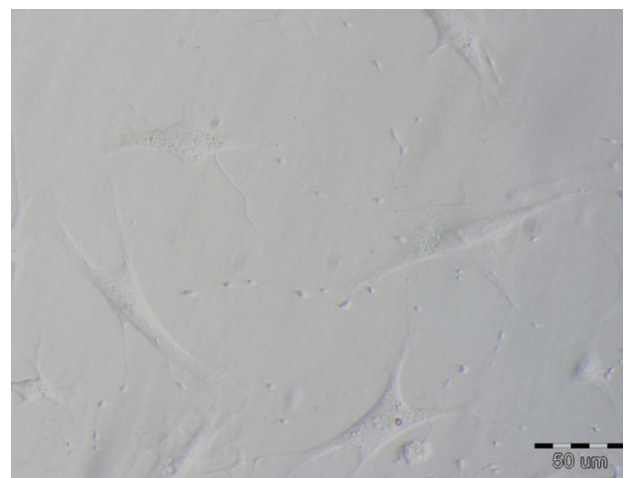

(b)

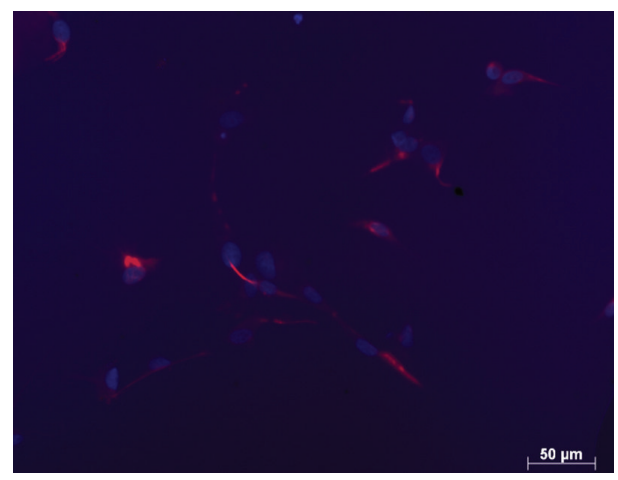

(d)

FIGURE 1: Representative morphology of cultured equine endometrial: (a) epithelial cells and (b) stromal cells. (c) Epithelial cells identification by immunofluorescent staining for cytokeratin; (d) stromal cells identification by immunofluorescent staining for vimentin. The scale bar = $50 \mu \mathrm{m}$ (magnification: $\times 40)$.

Culture. Stromal $(n=5)$ and epithelial $(n=5)$ cells derived from passage I were placed in a 24 -well plate. When the cells reached $90 \%$ of confluence, the medium was replaced with fresh DMEM without phenol red supplemented with $0.1 \%$ BSA and antibiotics and antimycotic. Epithelial and stromal cells were incubated with vehicle or with $\mathrm{P}_{4}\left(10^{-7} \mathrm{M}\right), \mathrm{E}_{2}$ $\left(10^{-9} \mathrm{M}\right)$ or $\mathrm{P}_{4}+\mathrm{E}_{2}\left(10^{-7} \mathrm{M} / 10^{-9} \mathrm{M}\right)$ added to the culture medium for $24 \mathrm{~h}$. After that, culture medium was removed and cells were washed twice with PBS. To each well $250 \mu \mathrm{L}$ of Fenozol was added and the cells were removed and kept frozen until RNA isolation.

\subsection{Methods}

2.4.1. Total RNA Isolation and cDNA Synthesis. Total RNA was extracted from epithelial and stromal cells from Experiment 2, after culture using the Total RNA Prep Plus Kit (A\&A Biotechnology, Gdansk, Poland) according to the manufacturer's instructions. Ribonucleic acid samples were stored at $-80^{\circ} \mathrm{C}$. Before use, RNA concentration and quality were determined spectrophotometrically and with agarose gel electrophoresis. The absorbance ratio at $260 \mathrm{~nm}$ and $280 \mathrm{~nm}\left(\mathrm{~A}_{260 / 280}\right)$ was approximately 2 . The amount of $1 \mu \mathrm{g}$ of RNA was reversed transcribed into cDNA using a QuantiTect Reverse Transcription Kit (Qiagen, \#205311) according to the manufacturer's instruction. The cDNA was stored at $-20^{\circ} \mathrm{C}$ until real-time PCR was carried out.

2.4.2. Real-Time PCR. Real-time PCR was performed with an ABI Prism 7300 sequence detection system using SYBR Green PCR master mix (Applied Biosystems, Foster City, CA, USA, \#4309155). The sequences for equine IL-1RI, IL$1 R I I, I L-6 R \beta$, and $A C T B$ primers were previously published [23]. After a preliminary study, ACTB was chosen as the best housekeeping gene. All primers were synthesized by GenoMed (Warszawa, Poland). Total reaction volume was $20 \mu \mathrm{L}$ and contained $1 \mu \mathrm{L}$ cDNA $(1 \mathrm{ng} / \mu \mathrm{L}), 2 \mu \mathrm{L}$ forward and reverse primers each $(250 \mathrm{nM})$ and $10 \mu \mathrm{L}$ SYBR Green PCR master mix. Real-time PCR was carried out as follows: initial denaturation $\left(10 \mathrm{~min}\right.$ at $\left.95^{\circ} \mathrm{C}\right)$, followed by 40 cycles of denaturation $\left(15 \mathrm{~s}\right.$ at $\left.95^{\circ} \mathrm{C}\right)$ and annealing $\left(1 \mathrm{~min}\right.$ at $\left.60^{\circ} \mathrm{C}\right)$. After each PCR reaction, melting curves were obtained by stepwise increases in temperature from 60 to $95^{\circ} \mathrm{C}$ to ensure single product amplification. The product specificity was also confirmed by electrophoresis on $2 \%$ agarose gel. The data were analyzed using the method described by Zhao and Fernald [24].

2.4.3. PG and Ovarian Steroids Determination. The concentration of $\mathrm{PGE}_{2}$ in the conditioned medium was determined 
using Prostaglandin $\mathrm{E}_{2}$ EIA kit (Cayman) according to the manufacturer's instruction. The concentration of $\mathrm{PGF}_{2 \alpha}$ was determined using the direct enzyme immunoassay (EIA) method as described previously by Uenoyama et al. [25] with modification. The standard curve for $\mathrm{PGE}_{2}$ ranged from $16.5 \mathrm{pg} / \mathrm{mL}$ to $1000 \mathrm{pg} / \mathrm{mL}$. The intra- and interassay coefficients of variation $(\mathrm{CV})$ were $3.9 \%$ and $8.1 \%$, respectively. The standard curve for $\mathrm{PGF}_{2 \alpha}$ ranged from $0.19 \mathrm{ng} / \mathrm{mL}$ to $50 \mathrm{ng} / \mathrm{mL}$ and $\mathrm{CV}$ were $4.7 \%$ and $9.8 \%$, respectively.

The concentration of $\mathrm{P}_{4}$ in blood plasma was determined using EIA as described previously [26]. The standard curve for $\mathrm{P}_{4}$ ranged from $0.0925 \mathrm{ng} / \mathrm{mL}$ to $25 \mathrm{ng} / \mathrm{mL}$ and intraand interassay $\mathrm{CV}$ were $3.7 \%$ and $8.4 \%$, respectively. The antibodies (Anti-P4, code SO/91/4; kindly donated by Dr. S. Okrasa, Warmia-Mazury University, Olsztyn, Poland) were characterized previously [27].

The concentrations of $\mathrm{E}_{2}$ in blood serum were assayed by radioimmunoassay (RIA) after extraction with diethyl ether (extraction efficiency: 89\%) as described [28]. The antibody (Anti-E2, code BS/88/754; gift from Dr. B. Szafranska, Warmia-Mazury University, Olsztyn, Poland) was characterized previously [29]. The intra- and interassay $\mathrm{Cv}$ averaged $4.2 \%$ and $8.1 \%$, respectively. The $\mathrm{E}_{2}$ standard curve ranged from 0.5 to $80 \mathrm{pg} / \mathrm{mL}$, and the effective dose for $50 \%$ inhibition (ED50) of the assay was $1.98 \mathrm{pg} / \mathrm{mL}$. The intra- and interassay $\mathrm{Cv}$ averaged $5.2 \%$ and $9.5 \%$, respectively.

2.5. Statistical Analysis. The data are shown as the mean \pm SEM of values obtained in separate experiments, each performed in quadruplicate. The statistical analysis of Experiment 1 and Experiment 3 was performed using parametric one-way ANOVA followed by Newmann-Keuls comparison test (GraphPad Software version 5, San Diego, USA). The statistical analysis of Experiment 2 was performed using nonparametric one-way ANOVA Kruskala-Wallisa followed by Dunns test. The results were considered significantly different when $P<0.05$.

\section{Results}

3.1. Experiment 1: The Effect of Ovarian Steroids on Epithelial and Stromal Cell Proliferation. Interleukins $1 \alpha$ and IL6 augmented epithelial cell proliferation compared to the control group (Figure 2(a); $P<0.01$ ). In turn, only IL-6 augmented stromal cell proliferation compared to the control group (Figure 2(b); $P<0.01$ ).

3.2. Experiment 2: The Effect of Ovarian Steroids on CytokineStimulated PG Production by Endometrial Cells. The basal in vitro $\mathrm{PGE}_{2}$ and $\mathrm{PGF}_{2 \alpha}$ secretion from epithelial cells was $1.60 \pm 0.924 \mathrm{ng} / \mu \mathrm{g}$ DNA and $2.63 \pm 0.343 \mathrm{ng} / \mu \mathrm{g}$ DNA, respectively. The basal in vitro $\mathrm{PGE}_{2}$ and $\mathrm{PGF}_{2 \alpha}$ secretion from stromal cells was $2.02 \pm 0.332 \mathrm{ng} / \mu \mathrm{g}$ DNA and $1.38 \pm$ $0.231 \mathrm{ng} / \mu \mathrm{g}$ DNA, respectively. Oxytocin (positive control) augmented $\mathrm{PGE}_{2}$ and $\mathrm{PGF}_{2 \alpha}$ secretion from epithelial cells stromal cells compared to the respective control group $(P<$ 0.05; Figure 3 to Figure 5).
Interleukin $1 \alpha$ augmented $\mathrm{PGE}_{2}$ and $\mathrm{PGF}_{2 \alpha}$ by epithelial $(P<0.01 ; P<0.05$; respectively; Figures 3(a) and 3(c)) and stromal cells $(P<0.05$; Figures $3(\mathrm{~b})$ and 3(d) compared to the respective control group. Epithelial cells pretreatment with $\mathrm{E}_{2}$ or $\mathrm{P}_{4}+\mathrm{E}_{2}$ decreased IL- $1 \alpha$-stimulated $\mathrm{PGE}_{2}$ secretion compared to the only IL- $1 \alpha$-stimulated group $(P<0.05$; Figure 3(a)). However, epithelial cells pretreatment with $\mathrm{E}_{2}$ or $\mathrm{P}_{4}+\mathrm{E}_{2}$ augmented IL- $1 \alpha$-stimulated $\mathrm{PGF}_{2 \alpha}$ secretion compared to only IL-1 $\alpha$-stimulated group $(P<$ 0.01 ; Figure $3(\mathrm{c}))$. Stromal cells pretreatment with $\mathrm{E}_{2}$ or $\mathrm{P}_{4}+\mathrm{E}_{2}$ augmented IL- $1 \alpha$-stimulated $\mathrm{PGE}_{2}(P<0.001$; Figure 6(b)) and $\mathrm{PGF}_{2 \alpha}(P<0.001$; Figure 3(d)) secretion compared to the respective only IL- $1 \alpha$-stimulated group.

Interleukin $1 \beta$ augmented $\mathrm{PGE}_{2}$ and $\mathrm{PGF}_{2 \alpha}$ by epithelial $(P<0.05 ; P<0.01$; respectively, Figures $4(\mathrm{a})$ and $4(\mathrm{c}))$ and stromal cells $(P<0.05 ; P<0.01$; respectively, Figures 4 (b) and $4(\mathrm{~d}))$ compared to the respective control group.

Epithelial cell pretreatment with $\mathrm{P}_{4}+\mathrm{E}_{2}$ augmented IL- $1 \beta$-stimulated $\mathrm{PGE}_{2}$ compared to only IL- $1 \beta$-stimulated group $(P<0.01$; Figure 4(a)). Stromal cells pretreatment with $\mathrm{E}_{2}$ or $\mathrm{P}_{4}+\mathrm{E}_{2}$ augmented IL- $1 \beta$-stimulated $\mathrm{PGE}_{2}$ secretion compared to only IL-1 $\beta$-stimulated group $(P<$ 0.01 ; Figure $4(\mathrm{~b}))$. But stromal cells pretreatment with $\mathrm{P}_{4}$ decreased IL- $1 \beta$-stimulated PGE $_{2}$ compared to only IL- $1 \beta$ stimulated group $(P<0.05$; Figure $4(\mathrm{~b}))$. In turn, stromal cell pretreatment with $\mathrm{P}_{4}, \mathrm{E}_{2}$, or $\mathrm{P}_{4}+\mathrm{E}_{2}$ augmented IL- $1 \beta$ stimulated $\mathrm{PGF}_{2 \alpha}$ compared to only IL- $1 \beta$-stimulated group $(P<0.001$; Figure $4(\mathrm{~d}))$.

Interleukin 6 augmented $\mathrm{PGE}_{2}$ and $\mathrm{PGF}_{2 \alpha}$ secretion by epithelial cells $(P<0.05$; Figures 5(a) and 5(c)) and $\mathrm{PGF}_{2 \alpha}$ secretion by stromal cells $(P<0.05 ; P<0.01$; respectively, Figure 5(d)) compared to respective control group. Epithelial cell pretreatment with $\mathrm{E}_{2}$ augmented IL-6stimulated $\mathrm{PGE}_{2}$ secretion compared to only IL-6-stimulated group $(P<0.01$; Figure 5(a)). Additionally, stromal cell pretreatment with $\mathrm{E}_{2}$ or $\mathrm{P}_{4}+\mathrm{E}_{2}$ augmented IL-6-stimulated $\mathrm{PGE}_{2}$ secretion compared to only IL-6-stimulated group $(P<$ 0.01; Figure 5(b)). Stromal cell pretreatment with $\mathrm{P}_{4}, \mathrm{E}_{2}$ or $\mathrm{P}_{4}$ $+\mathrm{E}_{2}$ augmented IL-6-stimulated $\mathrm{PGF}_{2 \alpha}$ secretion compared to only IL-6-stimulated group $(P<0.01$; Figure $5(\mathrm{~d}))$.

3.3. Experiment 3: The Effect of Ovarian Steroids on IL Receptor $m R N A s$ Transcription In Epithelial and Stromal Cells Culture. 17- $\beta$ estradiol and/or $\mathrm{P}_{4}$ upregulated $I L-1 R I$ mRNA transcription in epithelial cell compared to control group $\left(P<0.01\right.$; Figure 6(a)). 17- $\beta$ estradiol or $\mathrm{P}_{4}$ upregulated $I L-1 R I I$ mRNA transcription in epithelial cells compared to control group $\left(P<0.001\right.$; Figure 6(c)). In turn, $\mathrm{E}_{2}$ downregulated $I L-1 R I$ and P4 + E2 downregulated IL-1RII mRNA transcription in stromal cells compared to control group $(P<0.001$; Figures $6(\mathrm{~b})$ and $6(\mathrm{~d}))$. 17- $\beta$ estradiol and $\mathrm{P}_{4}+\mathrm{E}_{2}$ upregulated $I L-6 R \beta$ mRNA transcription in epithelial cells compared to control group $(P<0.01$; Figure 6(e)). 17- $\beta$ estradiol and/or $\mathrm{P}_{4}$ upregulated $I L-6 R \beta$ mRNA transcription in stromal cells compared to control group $(P<0.05$; Figure 6(f)). Additionally, $\mathrm{E}_{2}$ and $\mathrm{P}_{4}+\mathrm{E}_{2}$ increased the IL-1RI/IL-1RII mRNA transcription ratio in epithelial and stromal cells $(P<0.05$; Figures $7(\mathrm{a})$ and $7(\mathrm{~b}))$. 


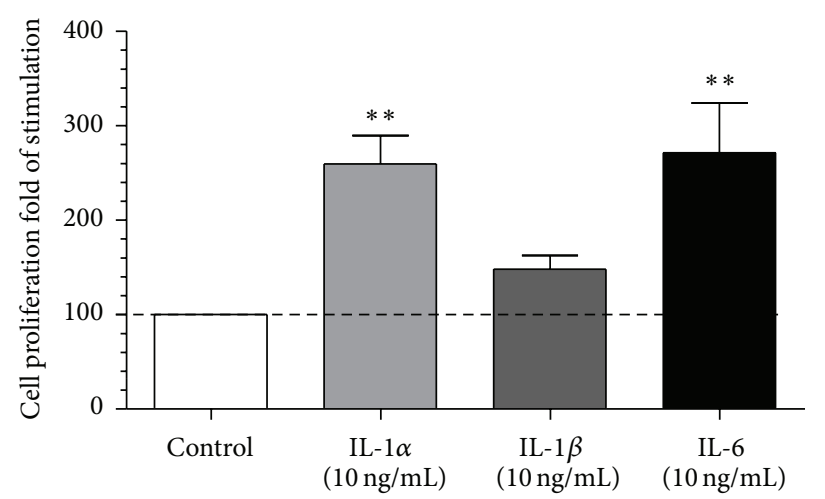

(a)

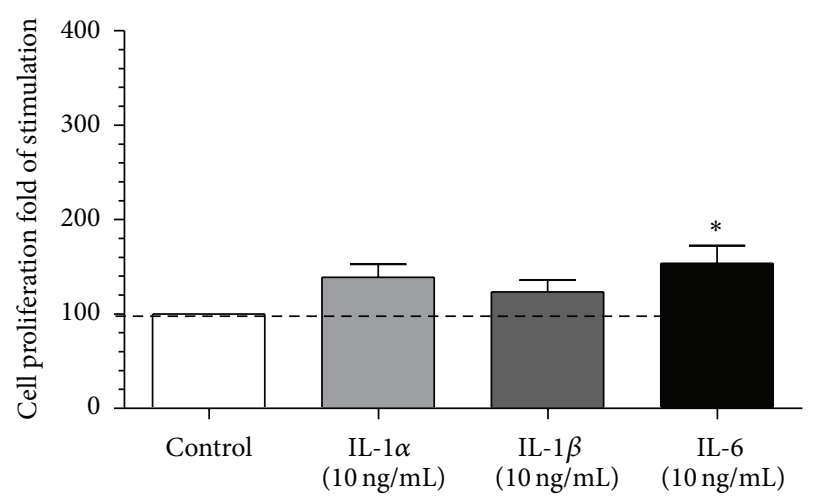

(b)

FIGURE 2: The effect of IL- $1 \alpha(10 \mathrm{ng} / \mathrm{mL})$, IL-1 $\beta(10 \mathrm{ng} / \mathrm{mL})$, or IL-6 $(10 \mathrm{ng} / \mathrm{mL})$ on proliferation of (a) epithelial cells $(\mathrm{mean} \pm$ SEM; $n=5)$ and (b) stromal cells (mean \pm SEM; $n=5$ ) after $24 \mathrm{~h}$ incubation. All values are expressed as $n$-fold change from control. Asterisks indicate significant differences $\left({ }^{*} P<0.05 ;{ }^{* *} P<0.01\right)$ from the respective control, as determined by parametric one-way ANOVA followed by Newmann-Keuls comparison test.

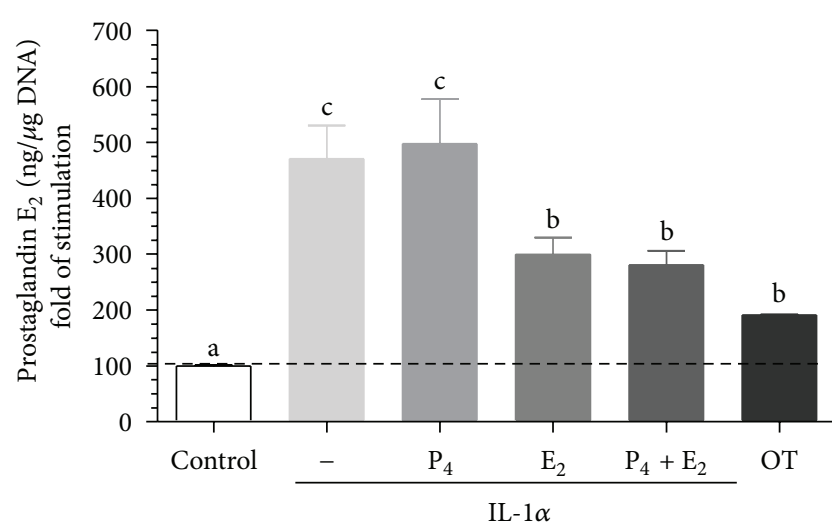

(a)

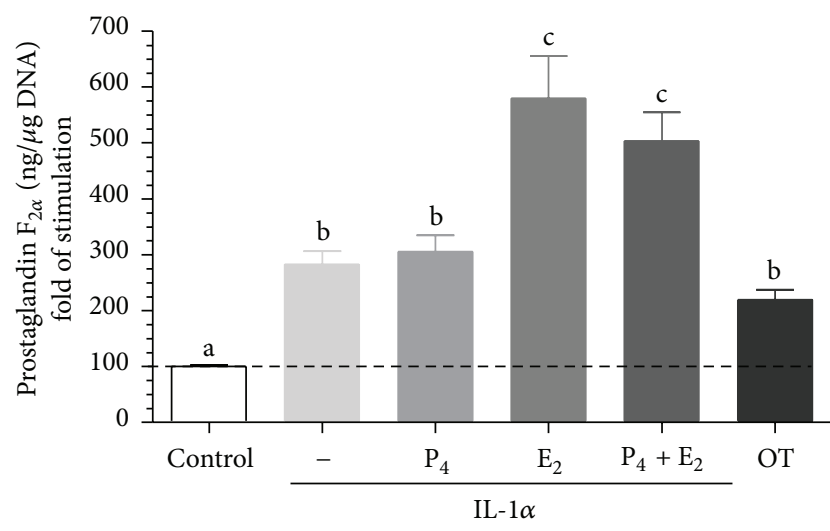

(c)

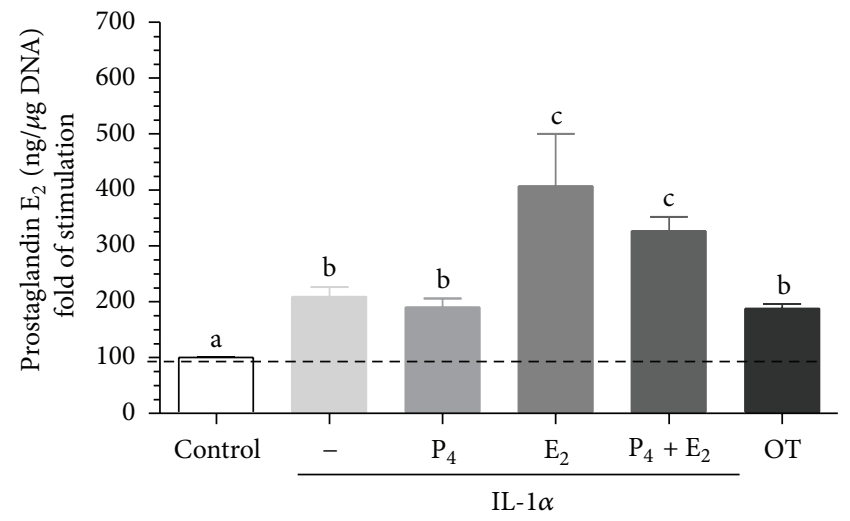

(b)

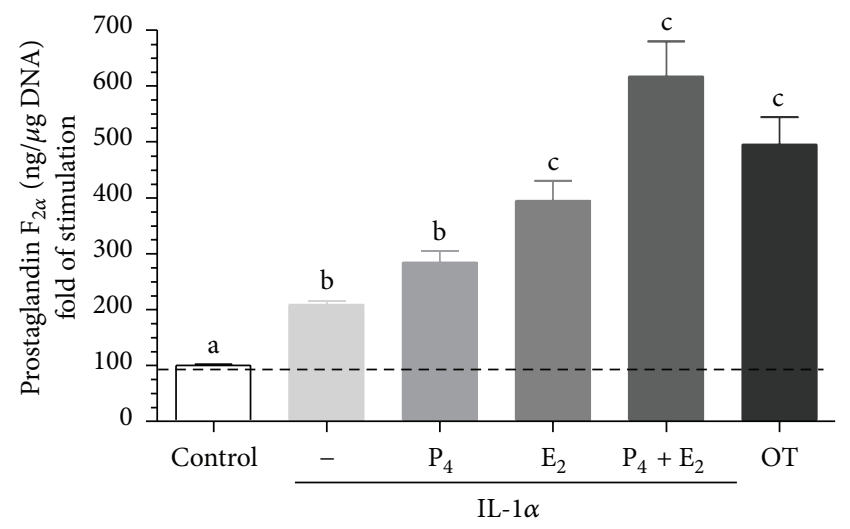

(d)

FIGURE 3: The effect of ovarian steroids on IL-1 $\alpha$ stimulated $\mathrm{PGE}_{2}$ and $\mathrm{PGF}_{2 \alpha}$ production by epithelial ((a), (c)) and stromal ((b), (d)) cells. The cells were treated with $\mathrm{P}_{4}\left(10^{-7} \mathrm{M}\right), \mathrm{E}_{2}\left(10^{-9} \mathrm{M}\right)$, or $\mathrm{P}_{4}+\mathrm{E}_{2}\left(10^{-7} / 10^{-9} \mathrm{M}\right)$ for $24 \mathrm{~h}$. Then, the medium was replaced with a fresh medium and the epithelial cells were stimulated with IL- $1 \alpha(10 \mathrm{ng} / \mathrm{mL})$ for $24 \mathrm{~h}$. Oxytocin $\left(\mathrm{OT} ; 10^{-7} \mathrm{M}\right)$ was used as a positive control. All values are expressed as $n$-fold change from control. letters "a," "b," and "c" indicate significant differences $(P<0.05)$ between groups, as determined by parametric one-way ANOVA followed by Newmann-Keuls comparison test. 


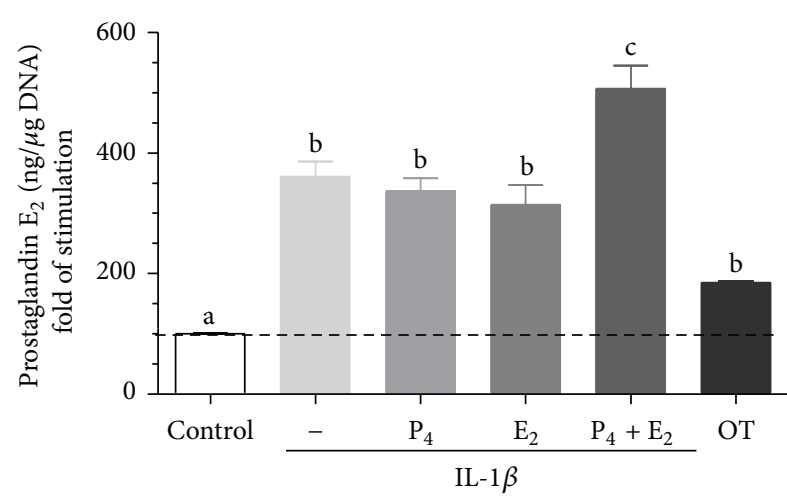

(a)

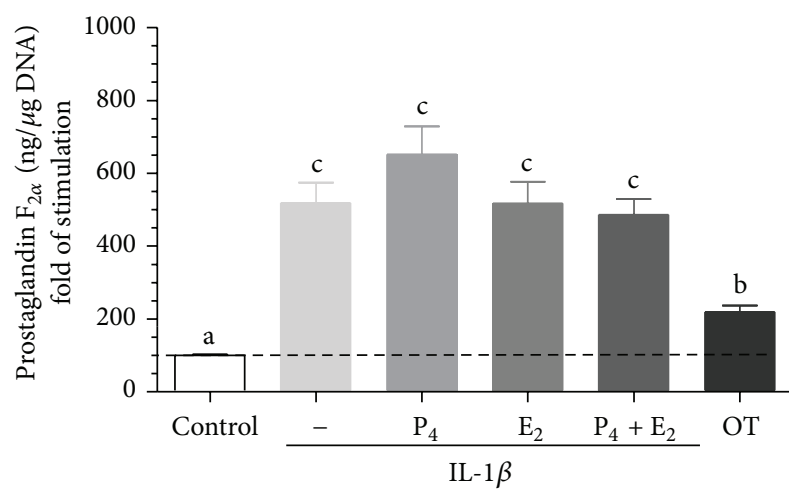

(c)

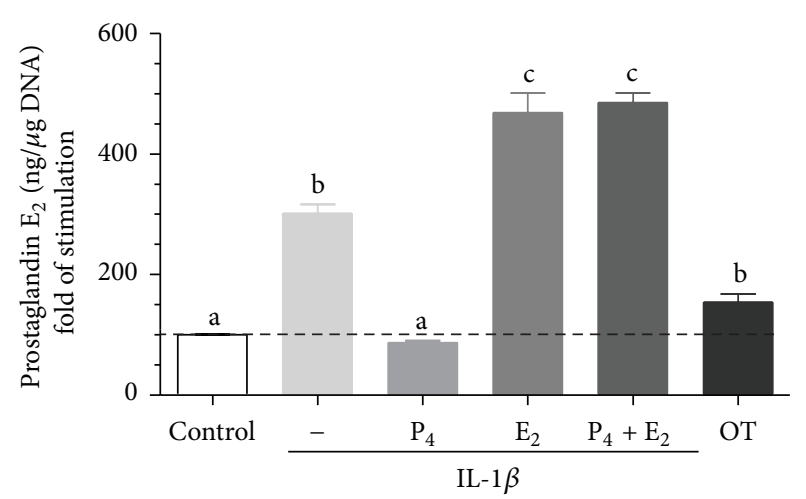

(b)

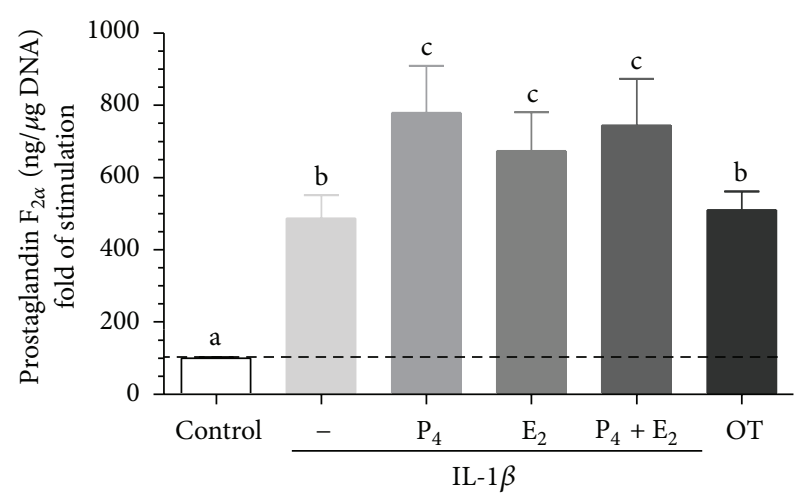

(d)

FIGURE 4: The effect of ovarian steroids on IL-1 $\beta$ stimulated $\mathrm{PGE}_{2}$ and $\mathrm{PGF}_{2 \alpha}$ production by epithelial ((a), (c)) and stromal ((b), (d)) cells. The cells were treated with $\mathrm{P}_{4}\left(10^{-7} \mathrm{M}\right), \mathrm{E}_{2}\left(10^{-9} \mathrm{M}\right)$, or $\mathrm{P}_{4}+\mathrm{E}_{2}\left(10^{-7} / 10^{-9} \mathrm{M}\right)$ for $24 \mathrm{~h}$. Then, the medium was replaced with a fresh medium and the epithelial cells were stimulated with IL-1 $\beta(10 \mathrm{ng} / \mathrm{mL})$ for $24 \mathrm{~h}$. Oxytocin $\left(\mathrm{OT} ; 10^{-7} \mathrm{M}\right)$ was used as a positive control. All values are expressed as $n$-fold change from control. letters "a," "b," "c" indicate significant differences $(P<0.05)$ between groups, as determined by parametric one-way ANOVA followed by Newmann-Keuls comparison test.

\section{Discussion}

A short number of studies characterized IL in the equine endometrium $[23,30]$. However, we have recently described IL- $1 \alpha$, IL- $1 \beta$, and IL- 6 immunolocalization in the equine endometrium [23]. We also showed that those ILs stimulated PG secretion through the upregulation of $P G$ synthases mRNAs transcription in endometrial explants in vitro [23]. Additionally, the equine endometrial upregulation of $I L-1 \alpha$ and $I L-6$ mRNAs transcription together with an upward tendency in $I L-1 \beta$ mRNA transcription was demonstrated in early pregnancy [30]. However, it has been shown that ovarian steroids did not affect $I L-1 \alpha$ and $I L-6$ mRNAs transcription in endometrial explants in vitro [30].

Interleukins stimulate $\mathrm{PG}$ production by endometrium in many species besides the mare [12, 31-34]. Tamura et al. [33] and Huang et al. [34] showed that IL-1 $\beta$ upregulated PGE2 secretion and PTGS-2 mRNA transcription in human stromal endometrial cells. Furthermore, the ability to produce PG in response to IL- $1 \alpha$ in rat stromal cells was confirmed by Bany and Kennedy [31]. In turn, Chen et al. [32] confirmed that human epithelial cells are able to produce PG in response to IL- $1 \alpha$ if the culture medium is supplemented with arachidonic acid (AA). Several previous studies present diverse conclusions [12, 31-35]. Tanikawa et al. [12] showed that IL1 $\alpha$ and IL1 $\beta$ stimulated in a dose-dependent manner both PGE2 and PGF2 $\alpha$ production in bovine stromal cells, but this stimulatory effect of both IL1s was not observed in epithelial cells. Nonetheless, Betts and Hansen [35] showed that IL$1 \beta$ had no effect on PG production in bovine stromal cells, but augmented PGE2 and PGF $2 \alpha$ production by epithelial cells. A comprehensive study concerning IL-6 influence on PG production by endometrial cells is lacking. Our previous data showed that IL- 6 stimulated PG production by equine endometrial explants in vitro [23].

Cyclic changes in the endometrium are a complex process governed by the interplay of several signaling pathways that critically regulate cell growth and proliferation. Ovarian steroids play a key role in these processes. In the present study, we showed that ovarian steroids are not only triggering endometrial PG production, but they also modulate endometrial cell response to IL. As previously shown, ovarian steroids stimulated PG production by equine of epithelial and stromal cells [4]. The analysis of our present findings shows that $\mathrm{E}_{2}$ can be a modulator of endometrial cell response to IL. Additionally, it was found that the response to IL- $1 \alpha$ and IL- 6 could be strongly modulated, when compared to IL-1 $\beta$. 


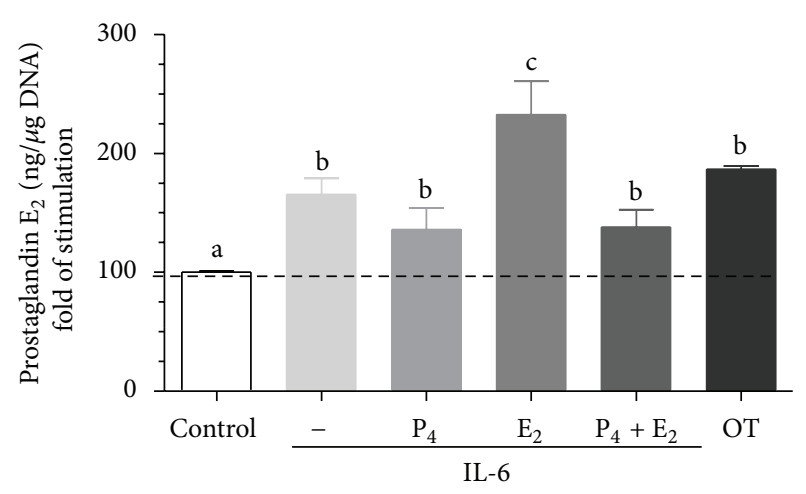

(a)

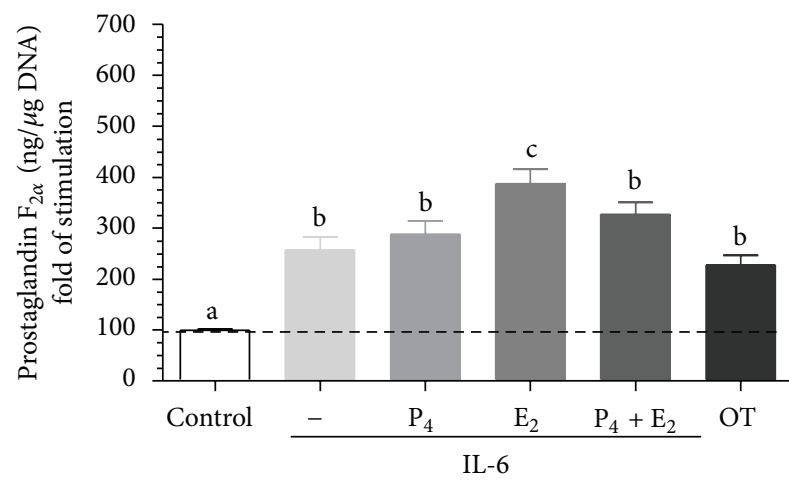

(c)

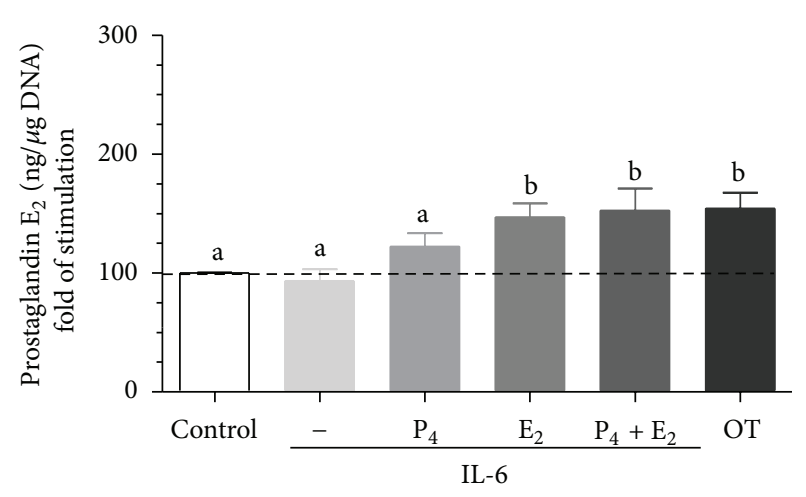

(b)

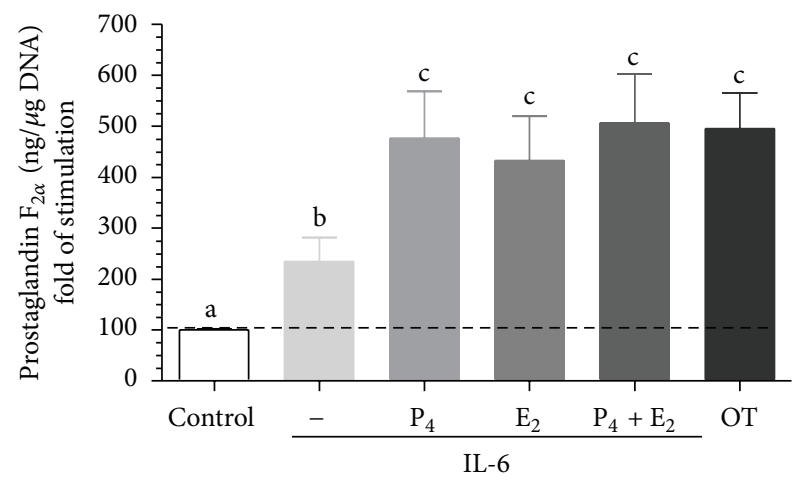

(d)

FIGURE 5: The effect of ovarian steroids on IL-6 stimulated PGE 2 and PGF $_{2 \alpha}$ production by epithelial ((a), (c)) and stromal ((b), (d)) cells. The cells were treated with $\mathrm{P}_{4}\left(10^{-7} \mathrm{M}\right), \mathrm{E}_{2}\left(10^{-9} \mathrm{M}\right)$, or $\mathrm{P}_{4}+\mathrm{E}_{2}\left(10^{-7} / 10^{-9} \mathrm{M}\right)$ for $24 \mathrm{~h}$. Then, the medium was replaced with a fresh medium and the epithelial cells were stimulated with IL-6 $(10 \mathrm{ng} / \mathrm{mL})$ for $24 \mathrm{~h}$. Oxytocin $\left(\mathrm{OT} ; 10^{-7} \mathrm{M}\right)$ was used as a positive control. All values are expressed as $n$-fold change from control. letters "a," "b," and "c" indicate significant differences $(P<0.05)$ between groups, as determined by parametric one-way ANOVA followed by Newmann-Keuls comparison test.

It was shown that in the mare IL- $1 \alpha$ and IL-6, expression is upregulated during the follicular phase of the estrous cycle, following $\mathrm{E}_{2}$ action [23]. It should be highlighted that the endometrial tissue response to acting factors results from epithelial and stromal cell activity. Our findings showed that the influence of ovarian steroids on IL- $1 \alpha$-stimulated PG production is dependent on the cell or PG types. Additionally, we showed that IL-6-stimulated PG production is strongly increased by $E_{2}$. Interestingly, although we had seen no effect of IL- 6 on PGE $_{2}$ secretion by stromal cells, the pretreatment with $\mathrm{E}_{2}$ and $\mathrm{P}_{4}+\mathrm{E}_{2}$ caused an increase of $\mathrm{PGE}_{2}$ secretion. In turn, the modulation of IL- $1 \beta$ influence on PG production by ovarian steroids is less evident, when compared to IL- $1 \alpha$ or IL-6. However, it should be noted that IL-1 $\beta$ alone has the strongest influence on $\mathrm{PG}$ production from endometrial cells compared to IL- $1 \alpha$ or IL- 6 . Regarding the present findings, the interaction between PG, IL, and ovarian steroids may be crucial for the local regulation of equine endometrium.

Baring in mind that endometrial IL- $1 \alpha$ and IL-6 expression are upregulated in follicular phase of the estrous cycle, their promotion of endometrial cell proliferation and also that $\mathrm{E}_{2}$ enhanced their support of PG production; it may be assumed that these cytokines may play a role in local changes, such as angiogenesis, cell proliferation, and other processes taking place in endometrium. Additionally, the cross-talk between PG, IL, and ovarian steroids is highly likely to be determinant for implantation.

17- $\beta$ estradiol positively affected IL- $1 \alpha$ - and IL-6stimulated $\mathrm{PGE}_{2}$ production may be a possible mechanism responsible for the angiogenesis regulation and cell proliferation in endometrium. Prostaglandin $E_{2}$ acts in an auto-/paracrine manner on proangiogenic factors such as vascular endothelial growth factor (VEGF) secretion and angiopoietin-1 and angiopoietin-2 expression [36-38]. Additionally, $\mathrm{PGE}_{2}$ and $\mathrm{PGF}_{2 \alpha}$ influenced epithelial cells proliferation in human endometrial cells $[7,8]$. Tsujii and DuBois [9] showed that $\mathrm{PGE}_{2}$ enhanced proliferation. It seems that IL- $1 \alpha$ and IL- 6 act on cell proliferation directly and indirectly by PG stimulation.

Once Haneda et al. [30] could not detect the link between ovarian steroids action and IL- $1 \alpha$ and IL- 6 expression around implantation period, it is possible that this interaction on that stage of the pregnancy is related to PG production. Synchronized development of the embryo to the blastocyst stage, endometrium differentiation to the receptive state, and cross-talk between the blastocyst and uterine luminal 


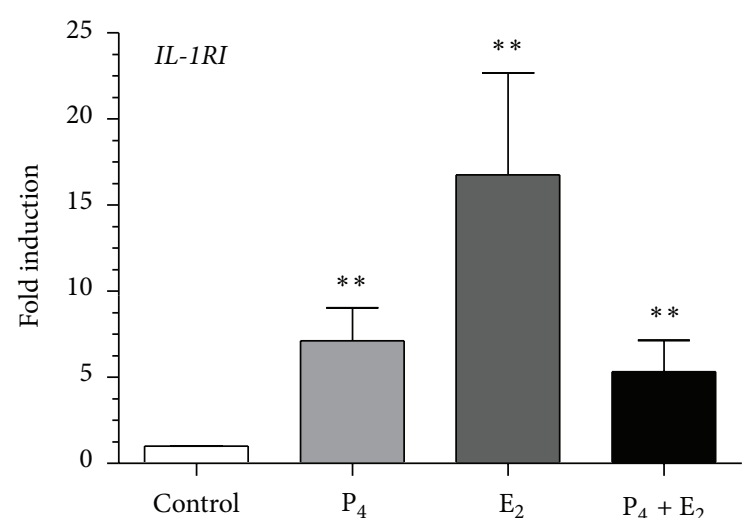

(a)

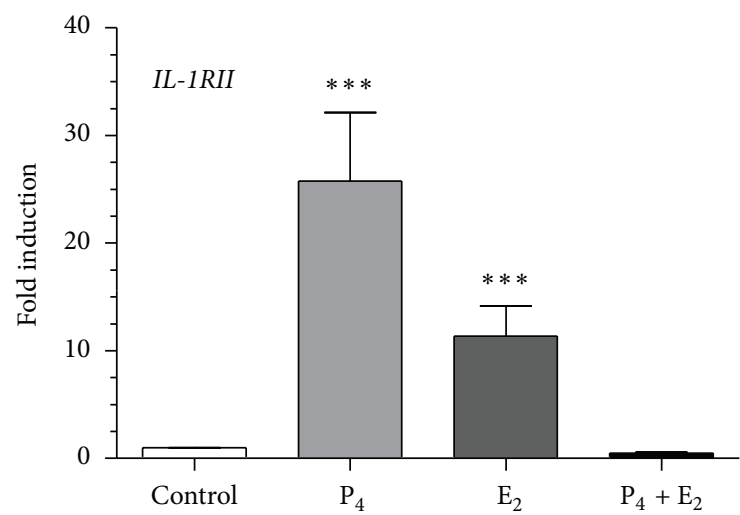

(c)

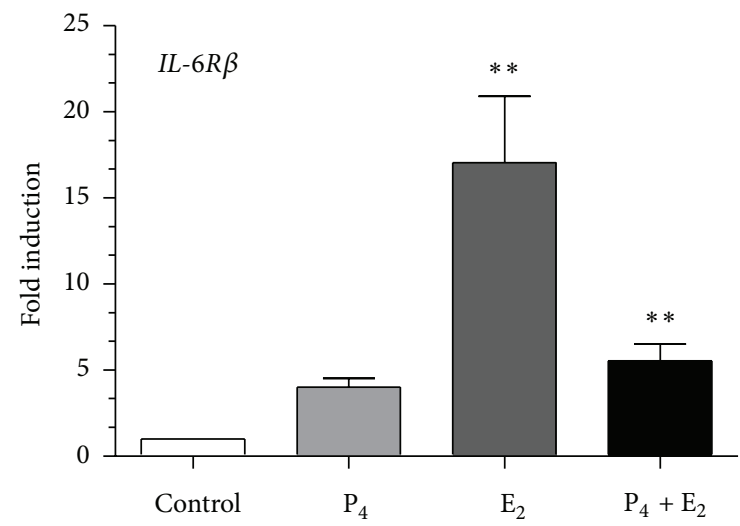

(e)

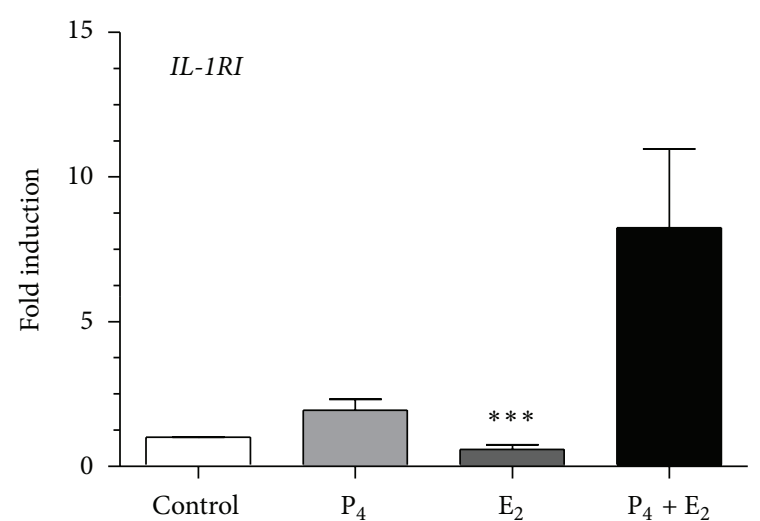

(b)

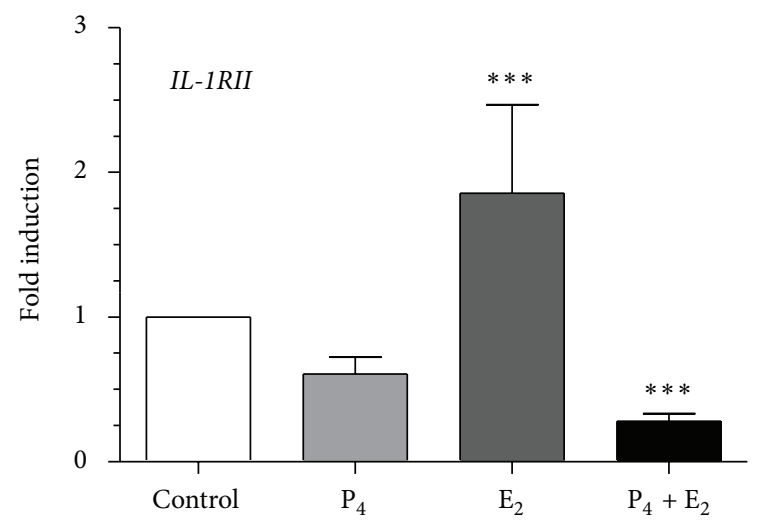

(d)

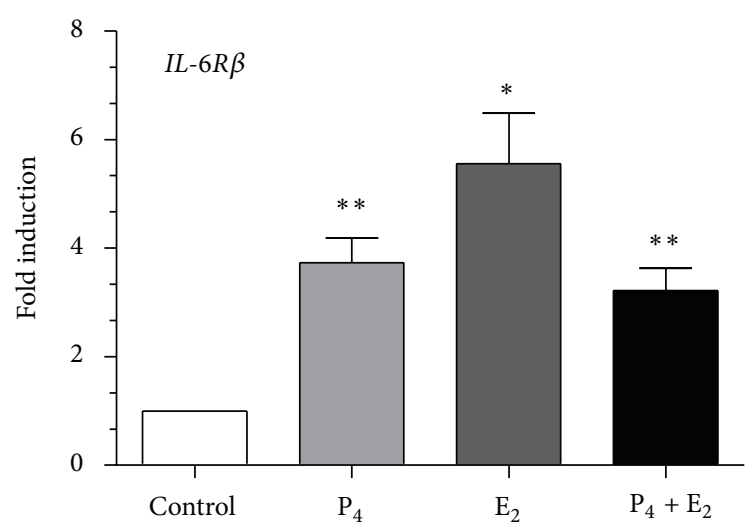

(f)

Figure 6: The effect of $\mathrm{P}_{4}\left(10^{-7} \mathrm{M}\right), \mathrm{E}_{2}\left(10^{-9} \mathrm{M}\right)$, and $\mathrm{P}_{4}+\mathrm{E}_{2}\left(10^{-7} / 10^{-9} \mathrm{M}\right)$ on $I L-1 R I((\mathrm{a}),(\mathrm{b})), I L-1 R I I((\mathrm{c}),(\mathrm{d}))$, and $I L-6 R \beta((\mathrm{e}),(\mathrm{f}))$ mRNA transcription in epithelial cells $(n=5)$ and stromal cells $(n=5)$ after $24 \mathrm{~h}$ incubation. Results are normalized against ACTB. Data are presented as fold induction relative to control. Asterisks indicate significant differences $\left({ }^{*} P<0.05\right.$; ${ }^{* *} P<0.01$; $\left.{ }^{* * *} P<0.001\right)$ from the respective control, as determined by nonparametric one-way ANOVA Kruskala-Wallisa followed by Dunns'a test.

epithelium are fundamental to the implantation process [39]. In mice and rats, $E_{2}$ is essential for preparation of the $\mathrm{P}_{4}$-primed uterus to the receptive state [39]. Various factors including cytokines, growth factors, homeobox transcription factors, and PG participate in embryo implantation through auto-/paracrine and/or juxtacrine mechanisms [39]. In contrast to other species, in the horse, the role of PG and IL on the embryo implantation is not described. It was demonstrated that the targeted disruption of PTGS-2 is the cause of multiple failures in murine female reproductive processes that include ovulation, fertilization, implantation, and decidualization [40,41]. The concentrations of PGs are elevated in the areas of increased endometrial vascular permeability associated with the initiation of implantation $[42,43]$ and exogenous PGs can reverse, at least partially, the effects of indomethacin on implantation in rat [44]. 


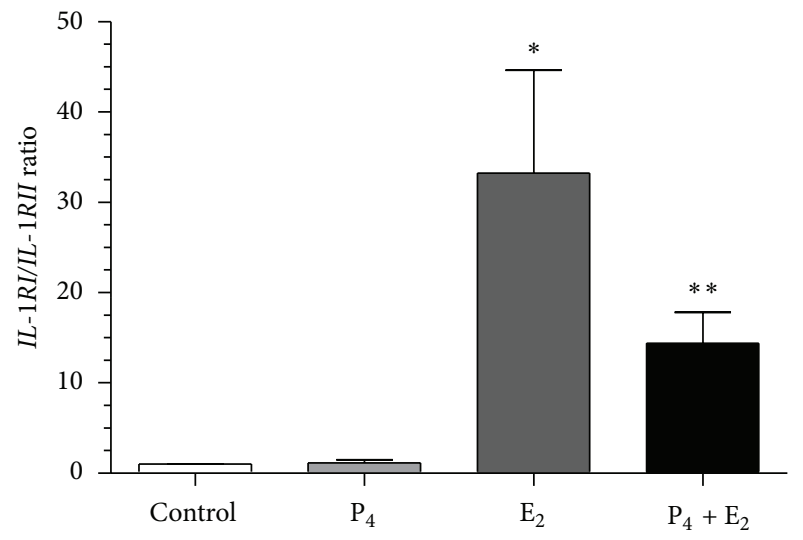

(a)

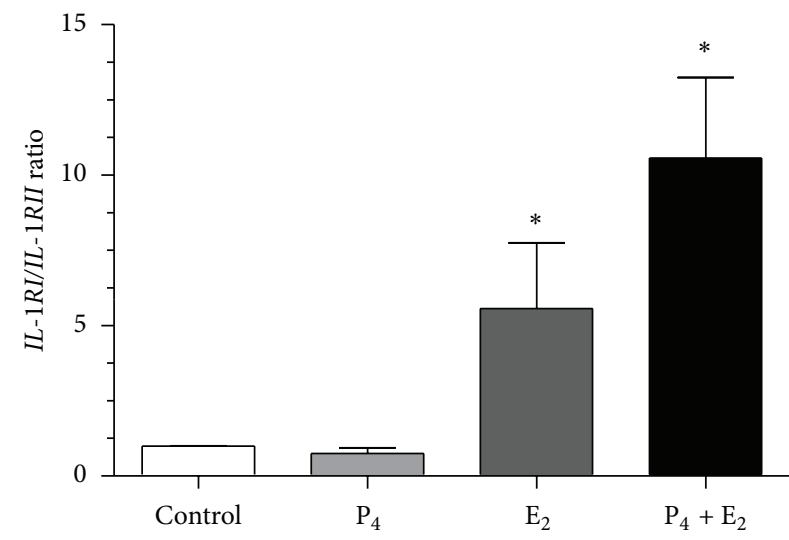

(b)

FIGURE 7: The effect of $\mathrm{P}_{4}\left(10^{-7} \mathrm{M}\right), \mathrm{E}_{2}\left(10^{-9} \mathrm{M}\right)$, and $\mathrm{P}_{4}+\mathrm{E}_{2}\left(10^{-7} / 10^{-9} \mathrm{M}\right)$ on $I L-1 R I$ :IL-1RII mRNA transcription ratio in epithelial cells $((\mathrm{a})$; $n=5)$ and stromal cells $((\mathrm{b}) ; n=5)$ after $24 \mathrm{~h}$ incubation. Results are normalized against ACTB. Asterisks indicate significant differences $\left({ }^{*} \mathrm{P}<0.05 ;{ }^{* *} \mathrm{P}<0.01\right)$ from the respective control, as determined by nonparametric one-way ANOVA Kruskala-Wallisa followed by Dunns'a test.

In turn, IL- $1 \alpha$ and IL- $\beta$ are involved in production of leukemia inhibitory factor (LIF) [45], granulocytemacrophage colony-stimulating factor (GM-CSF), and colony stimulating factor-1 (CSF-1) production [46]. Interleukin 1 stimulates production of metalloproteinases (MMP) and components of the plasminogen activator (PA)/PA-inhibitor cascade $[47,48]$ and also decreases connexin 43 in human endometrial stromal cells [49]. It has also been suggested that IL- 6 may contribute to trophoblast growth and placental development in humans [50]. In our present work we pointed out the potential interaction between $E_{2}$, IL, and PG. We suggest that $E_{2}$ modulation of IL- $1 \alpha$ - and IL-6-stimulated PG production during the preimplantation period may participate in event orchestration, including differentiation of endometrial cells and the vascular endothelial cell changes accompanying implantation and subsequent placental development. However, further studies are required to confirm these assumptions.

The pretreatment with combination of $\mathrm{P}_{4}$ and $\mathrm{E}_{2}$ augmented PG production in response to IL in endometrial cells. However, this enhancement, with one exception, was always followed by $\mathrm{E}_{2}$ increase of IL-stimulated PG production. Thus, one may conclude that $\mathrm{E}_{2}$ mainly increases IL-stimulated PG production. These results suggest that the mechanism responsible for enhancement of ILstimulated PG production by steroids is different in epithelial and stromal cells. In epithelial cells, this mechanism is associated to $I L-1 R I$ mRNA transcription after ovarian steroids treatment, suggesting that ovarian steroids increase IL-1 effect on PG production via upregulation of IL-1RI expression. In stromal cells, a single treatment with $\mathrm{E}_{2}$ and $\mathrm{P}_{4}$ did not affect IL-1RI mRNA transcription. Possible mediators of $\mathrm{E}_{2}$ action in stromal cells are protein kinase $\mathrm{A}$ (PKA), nuclear factor- $\kappa \mathrm{B}(\mathrm{NF}-\kappa \mathrm{B})$, and/or extracellularsignal-regulated kinases $1 / 2(\mathrm{ERK} 1 / 2)$, which have been reported to be involved in the control of PGE2 secretion and PTGS-2 expression in response to IL-1 $\beta$ in human stromal cells [51] and the upregulation of PTGS-2, through PKA activation in different types of tissues [52, 53]. As an example, $\mathrm{E}_{2}$ has been shown to interact with $\mathrm{NF} \kappa \mathrm{B}$ and to modulate its activity [54], stimulating PKA activity in hippocampal neurons $[55,56]$. However, new studies are required to clarify the enhancement of IL-stimulated PG production by steroids. Additionally, our findings confirmed that $\mathrm{E}_{2}$ regulates IL-6-stimulated $\mathrm{PG}$ production through upregulation of $I L-6 R \beta$ mRNA. However, the influence of $\mathrm{E}_{2}$ on IL-6R $\alpha$ expression should be investigated in the future.

In summary, it has been shown for the first time that $\mathrm{E}_{2}$ enhance IL- $1 \alpha$ and IL-6-stimulated PG production. It may be one of the mechanisms responsible for local orchestrating events in endometrial tissue during estrous cycle and implantation. Additionally, we suggest that $\mathrm{E}_{2}$ influence on IL-1- and IL-6-stimulated PG production may result from activation of $I L-1 R I$ and $I L-6 R \beta$ mRNAs transcription in endometrial cells.

\section{Conflict of Interests}

The authors declare that there is no conflict of interests regarding the publication of this paper.

\section{Acknowledgments}

This work was supported by Grant MAESTRO of the National Research Center and dedicated to DJS (no. 2011/02/A/NZ5/00338) and AZS and KO were supported by jointnPolish-Japanese project under agreement of PAS and JSPS. 


\section{References}

[1] M. W. Vernon, M. T. Zavy, R. L. Asquith, and D. C. Sharp, "Prostaglandin F2 $(\alpha)$ in the equine endometrium: steroid modulation and production capacities during the estrous cycle and early pregnancy," Biology of Reproduction, vol. 25, no. 3, pp. 581$589,1981$.

[2] M. T. Zavy, M. W. Vernon, and R. L. Asquith, "Effect of exogenous gonadal steroids and pregnancy on uterine luminal prostaglandin F in mares," Prostaglandins, vol. 27, no. 2, pp. 311320, 1984.

[3] A. Galvão, L. Valente, D. J. Skarzynski et al., "Effect of cytokines and ovarian steroids on equine endometrial function: an in vitro study," Reproduction, Fertility and Development, vol. 25, no. 7, pp. 985-997, 2013.

[4] A. Z. Szóstek, A. M. Galvão, G. M. Ferreira-Dias, and D. J. Skarzynski, "Ovarian steroids affect prostaglandin production in equine endometrial cells in vitro," Journal of Endocrinology, vol. 220, no. 3, pp. 267-276, 2014.

[5] D. J. Skarzynski, M. M. Bah, K. M. Deptula et al., "Roles of tumor necrosis factor- $\alpha$ of the estrous cycle in cattle: an in vivo study," Biology of Reproduction, vol. 69, no. 6, pp. 1907-1913, 2003.

[6] D. K. Vanderwall, G. L. Woods, J. A. Weber, and A. B. Lichtenwalner, "Corpus luteal function in nonpregnant mares following intrauterine administration of prostaglandin E2 or estradiol-17 $\beta$," Theriogenology, vol. 42, no. 7, pp. 1069-1083, 1994.

[7] H. N. Jabbour and S. C. Boddy, "Prostaglandin E2 induces proliferation of glandular epithelial cells of the human endometrium via extracellular regulated kinase 1/2-mediated pathway," The Journal of Clinical Endocrinology \& Metabolism, vol. 88, no. 9, pp. 4481-4487, 2003.

[8] S. A. Milne and H. N. Jabbour, "Prostaglandin (PG) F2 $\alpha$ receptor expression and signaling in human endometrium: role of PGF $2 \alpha$ in epithelial cell proliferation," Journal of Clinical Endocrinology and Metabolism, vol. 88, no. 4, pp. 1825-1832, 2003.

[9] M. Tsujii and R. N. DuBois, "Alterations in cellular adhesion and apoptosis in epithelial cells overexpressing prostaglandin endoperoxide synthase 2," Cell, vol. 83, no. 3, pp. 493-501, 1995.

[10] T. G. Kennedy, C. Gillio-Meina, and S. H. Phang, "Prostaglandins and the initiation of blastocyst implantation and decidualization," Reproduction, vol. 134, no. 5, pp. 635-643, 2007.

[11] M. Tanikawa, T. J. Acosta, T. Fukui et al., "Regulation of prostaglandin synthesis by interleukin- $1 \alpha$ in bovine endometrium during the estrous cycle," Prostaglandins and Other Lipid Mediators, vol. 78, no. 1-4, pp. 279-290, 2005.

[12] M. Tanikawa, H.-Y. Lee, K. Watanabe et al., "Regulation of prostaglandin biosynthesis by interleukin-1 in cultured bovine endometrial cells," Journal of Endocrinology, vol. 199, no. 3, pp. 425-434, 2008.

[13] M. Majewska, I. Woclawek-Potocka, M. M. Bah et al., "Is interleukin- $1 \alpha$ a luteotrophic or luteolytic agent in cattle?" Reproduction, vol. 139, no. 3, pp. 665-672, 2010.

[14] A. Franczak, A. Zmijewska, B. Kurowicka, B. Wojciechowicz, and G. Kotwica, "Interleukin $1 \beta$-induced synthesis and secretion of prostaglandin $\mathrm{E}_{2}$ in the porcine uterus during various periods of pregnancy and the estrous cycle," Journal of Physiology and Pharmacology, vol. 61, no. 6, pp. 733-742, 2010.

[15] A. Franczak, A. Zmijewska, B. Kurowicka, B. Wojciechowicz, B. K. Petroff, and G. Kotwica, "The effect of tumor necrosis factor $\alpha(\mathrm{TNF} \alpha)$, interleukin $1 \beta(\mathrm{IL} 1 \beta)$ and interleukin 6 (IL6) on endometrial PGF $2 \alpha$ synthesis, metabolism and release in early-pregnant pigs," Theriogenology, vol. 77, no. 1, pp. 155-165, 2012.

[16] C. A. Dinarello, "The IL-1 family and inflammatory diseases," Clinical and Experimental Rheumatology, vol. 20, no. 5, pp. S1S13, 2002.

[17] P. C. Heinrich, I. Behrmann, G. Müller-Newen, F. Schaper, and L. Graeve, "Interleukin-6-type cytokine signalling through the gp130/Jak/STAT pathway," Biochemical Journal, vol. 334, no. 2, pp. 297-314, 1998.

[18] R. P. Roberto da Costa, P. M. Serrão, S. Monteiro, P. Pessa, J. R. Silva, and G. Ferreira-Dias, "Caspase-3-mediated apoptosis and cell proliferation in the equine endometrium during the oestrous cycle," Reproduction, Fertility and Development, vol. 19, no. 8, pp. 925-932, 2007.

[19] A. M. Galvão, D. W. Ramilo, D. J. Skarzynski et al., "Is FAS/Fas ligand system involved in equine corpus luteum functional regression?" Biology of Reproduction, vol. 83, no. 6, pp. 901-908, 2010.

[20] O. J. Ginther, Reproductive Biology of the Mare: Basic and Applied Aspects, Equiservices, Cross Plains, Wis, USA, 2nd edition, 1992.

[21] R. M. Kenney, "Cyclic and pathologic changes of the mare endometrium as detected by biopsy, with a note on early embryonic death," Journal of the American Veterinary Medical Association, vol. 172, no. 3, pp. 241-262, 1978.

[22] A. Z. Szóstek, M. J. Siemieniuch, A. M. Galvão et al., "Effects of cell storage and passage on basal and oxytocin-regulated prostaglandin secretion by equine endometrial epithelial and stromal cells," Theriogenology, vol. 77, no. 8, pp. 1698-1708, 2012.

[23] A. Z. Szóstek, K. Lukasik, A. M. Galvão, G. M. Ferreira-Dias, and D. J. Skarzynski, "Impairment of the interleukin system in equine endometrium during the course of endometrosis," Biology of Reproduction, vol. 89, pp. 1-13, 2013.

[24] S. Zhao and R. D. Fernald, "Comprehensive algorithm for quantitative real-time polymerase chain reaction," Journal of Computational Biology, vol. 12, no. 8, pp. 1045-1062, 2005.

[25] Y. Uenoyama, S.-I. Hattori, M. Miyake, and K. Okuda, "Upregulation of oxytocin receptors in porcine endometrium by adenosine 3',5'-monophosphate," Biology of Reproduction, vol. 57, no. 4, pp. 723-728, 1997.

[26] D. Skarzynski, K. Piotrowska, M. Bah et al., "Effects of exogenous tumour necrosis factor- $\alpha$ on the secretory function of the bovine reproductive tract depend on tumour necrosis factor- $\alpha$ concentrations," Reproduction in Domestic Animals, vol. 44, no. 3, pp. 371-379, 2009.

[27] R. Ciereszko, M. Opałka, B. Kamińska, M. Wojtczak, S. Okrasa, and L. Dusza, "Luteotrophic action of prolactin during the early luteal phase in pigs: the involvement of protein kinases and phosphatases," Reproductive Biology, vol. 1, no. 2, pp. 62-83, 2001.

[28] R. Fitko, J. Kucharski, B. Szlezyngier, and B. Jana, “The concentration of GnRH in hypothalamus, $\mathrm{LH}$ and FSH in pituitary, LH, PRL and sex steroids in peripheral and ovarian venous plasma of hypo- and hyperthyroid, cysts-bearing gilts," Animal Reproduction Science, vol. 45, no. 1-2, pp. 123-138, 1996.

[29] B. Szafranska, A. J. Ziecik, and S. Okrasa, "Primary antisera against selected steroids or proteins and secondary antisera against ?-globulins-an available tool for studies of reproductive processes," Reproductive Biology, vol. 2, no. 2, pp. 187-204, 2002 . 
[30] S. Haneda, K. Nagaoka, Y. Nambo et al., "Interleukin-1 receptor antagonist expression in the equine endometrium during the peri-implantation period," Domestic Animal Endocrinology, vol. 36, no. 4, pp. 209-218, 2009.

[31] B. M. Bany and T. G. Kennedy, "Interleukin- $1 \alpha$ regulates prostaglandin production and cyclooxygenase activity in sensitized rat endometrial stromal cells in vitro," Biology of Reproduction, vol. 53, no. 1, pp. 126-132, 1995.

[32] D. B. Chen, Z. M. Yang, R. Hilsenrath, S.-P. Le, and M. J. K. Harper, "Stimulation of prostaglandin (PG) $\mathrm{F}(2 \alpha)$ and PGE2 release by tumour necrosis factor- $\alpha$ and interleukin$1 \alpha$ in cultured human luteal phase endometrial cells," Human Reproduction, vol. 10, no. 10, pp. 2773-2780, 1995.

[33] M. Tamura, S. Sebastian, S. Yang, B. Gurates, Z. Fang, and S. E. Bulun, "Interleukin- $1 \beta$ elevates cyclooxygenase- 2 protein level and enzyme activity via increasing its mRNA stability in human endometrial stromal cells: an effect mediated by extracellularly regulated kinases 1 and 2," The Journal of Clinical Endocrinology and Metabolism, vol. 87, no. 7, pp. 3263-3273, 2002.

[34] J.-C. Huang, D.-Y. Liu, S. Yadollahi, K. K. Wu, and M. Y. Dawood, "Interleukin- $1 \beta$ induces cyclooxygenase- 2 gene expression in cultured endometrial stromal cells," The Journal of Clinical Endocrinology \& Metabolism, vol. 83, no. 2, pp. 538541, 1998.

[35] J. G. Betts and P. J. Hansen, "Regulation of prostaglandin secretion from epithelial and stromal cells of the bovine endometrium by interleukin-1 $\beta$, interleukin-2, granulocytemacrophage colony stimulating factor and tumor necrosis factor- $\alpha$," Life Sciences, vol. 51, no. 14, pp. 1171-1176, 1992.

[36] M. Tsujii, S. Kawano, S. Tsuji, H. Sawaoka, M. Hori, and R. N. DuBois, "Cyclooxygenase regulates angiogenesis induced by colon cancer cells," Cell, vol. 93, no. 5, pp. 705-716, 1998.

[37] K. J. Sales, A. A. Katz, B. Howard, R. P. Soeters, R. P. Millar, and H. N. Jabbour, "Cyclooxygenase-1 is up-regulated in cervical carcinomas: autocrine/paracrine regulation of cyclooxygenase2, prostaglandin E receptors, and angiogenic factors by cyclooxygenase-1," Cancer Research, vol. 62, no. 2, pp. 424-432, 2002.

[38] M. M. Kaczmarek, A. Blitek, K. Kaminska et al., "Assessment of VEGF-receptor system expression in the porcine endometrial stromal cells in response to insulin-like growth factor-I, relaxin, oxytocin and prostaglandin E2," Molecular and Cellular Endocrinology, vol. 291, no. 1-2, pp. 33-41, 2008.

[39] B. C. Paria, J. Reese, S. K. Das, and S. K. Dey, "Deciphering the cross-talk of implantation: advances and challenges," Science, vol. 296, no. 5576, pp. 2185-2188, 2002.

[40] J. E. Dinchuk, B. D. Car, R. J. Focht et al., "Renal abnormalities and an altered inflammatory response in mice lacking cyclooxygenase II," Nature, vol. 378, no. 6555, pp. 406-409, 1995.

[41] H. Lim, B. C. Paria, S. K. Das et al., "Multiple female reproductive failures in cyclooxygenase 2-deficient mice," Cell, vol. 91, no. 2, pp. 197-208, 1997.

[42] T. G. Kennedy, "Evidence for a role for prostaglandins in the initiation of blastocyst implantation in the rat," Biology of Reproduction, vol. 16, no. 3, pp. 286-291, 1977.

[43] C. A. Evans and T. G. Kennedy, "The importance of prostaglandin synthesis for the initiation of blastocyst implantation in the hamster," Journal of Reproduction and Fertility, vol. 54, no. 2, pp. 255-261, 1978.

[44] M. Oettel, M. Koch, A. Kurischko, and K. Schubert, "A direct evidence for the involvement of prostaglandin F2 $(\alpha)$ in the first step of estrone-induced blastocyst implantation in the spayed rat," Steroids, vol. 33, no. 1, pp. 1-8, 1979.

[45] A. Arici, O. Engin, E. Attar, and D. L. Olive, "Modulation of leukemia inhibitory factor gene expression and protein biosynthesis in human endometrium," The Journal of Clinical Endocrinology \& Metabolism, vol. 80, no. 6, pp. 1908-1915, 1995.

[46] M. I. Garcia-Lloret, D. W. Morrish, T. G. Wegmann, L. Honore, A. R. Turner, and L. J. Guilbert, "Demonstration of functional cytokine-placental interactions: CSF-1 and GM-CSF stimulate human cytotrophoblast differentiation and peptide hormone secretion," Experimental Cell Research, vol. 214, no. 1, pp. 46-54, 1994.

[47] C. F. Singer, E. Marbaix, P. Lemoine, P. J. Courtoy, and Y. Eeckhout, "Local cytokines induce differential expression of matrix metalloproteinases but not their tissue inhibitors in human endometrial fibroblasts," European Journal of Biochemistry, vol. 259, no. 1-2, pp. 40-45, 1999.

[48] L. A. Salamonsen and G. Nie, "Proteases at the endometrialtrophoblast interface: their role in implantation," Reviews in Endocrine and Metabolic Disorders, vol. 3, no. 2, pp. 133-143, 2002.

[49] D. Semer, K. Reisler, P. C. MacDonald, and M. L. Casey, "Responsiveness of human endometrial stromal cells to cytokines," Annals of the New York Academy of Sciences, vol. 622, pp. 99-110, 1991.

[50] E. Nishino, N. Matsuzaki, K. Masuhiro et al., "Trophoblastderived interleukin-6 (IL-6) regulates human chorionic gonadotro-pin release through IL-6 receptor on human trophoblasts," The Journal of Clinical Endocrinology \& Metabolism, vol. 71, no. 2, pp. 436-441, 1990.

[51] M. Tamura, S. Sebastian, S. Yang, B. Gurates, Z. Fang, and S. E. Bulun, "Interleukin- $1 \beta$ elevates cyclooxygenase- 2 protein level and enzyme activity via increasing its mRNA stability in human endometrial stromal cells: an effect mediated by extracellularly regulated kinases 1 and 2," The Journal of Clinical Endocrinology \& Metabolism, vol. 87, no. 7, pp. 3263-3273, 2002.

[52] S. Choudhary, A. Kumar, R. K. Kale, L. G. Raisz, and C. C. Pilbeam, "Extracellular calcium induces COX-2 in osteoblasts via a PKA pathway," Biochemical and Biophysical Research Communications, vol. 322, no. 2, pp. 395-402, 2004.

[53] T. Gray, P. Nettesheim, C. Loftin et al., "Interleukin-1 $\beta$-induced mucin production in human airway epithelium is mediated by cyclooxygenase-2, prostaglandin E2 receptors, and cyclic AMP-protein kinase A signaling," Molecular Pharmacology, vol. 66, no. 2, pp. 337-346, 2004.

[54] R. Dai, R. A. Phillips, E. Karpuzoglu, D. Khan, and S. A. Ahmed, "Estrogen regulates transcription factors STAT-1 and NF- $\kappa \mathrm{B}$ to promote inducible nitric oxide synthase and inflammatory responses," The Journal of Immunology, vol. 183, no. 11, pp. 6998-7005, 2009.

[55] M. J. Kelly, A. H. Lagrange, E. J. Wagner, and O. K. Rønnekleiv, "Rapid effects of estrogen to modulate G protein-coupled receptors via activation of protein kinase A and protein kinase C pathways," Steroids, vol. 64, no. 1-2, pp. 64-75, 1999.

[56] A. S. Shingo and S. Kito, "Estradiol induces PKA activation through the putative membrane receptor in the living hippocampal neuron," Journal of Neural Transmission, vol. 112, no. 11, pp. 1469-1473, 2005. 


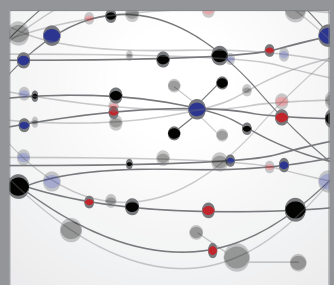

The Scientific World Journal
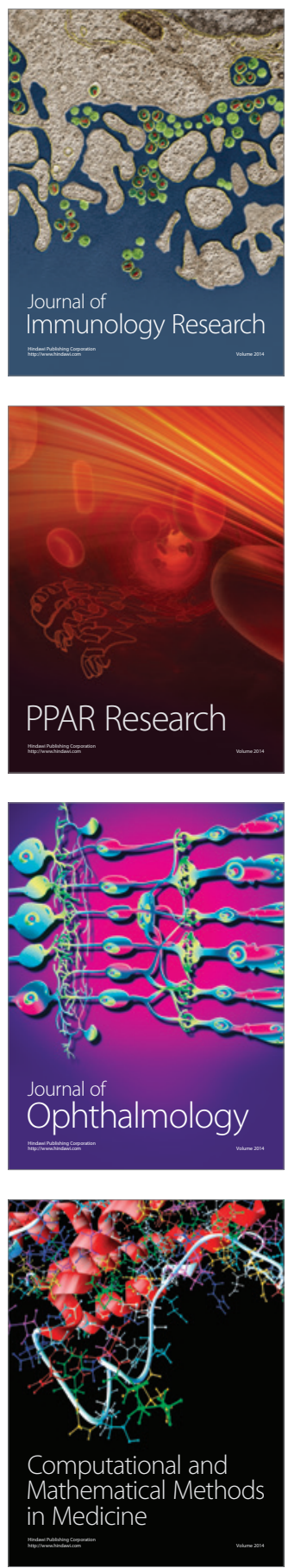

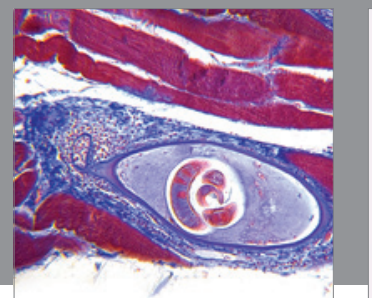

Gastroenterology

Research and Practice
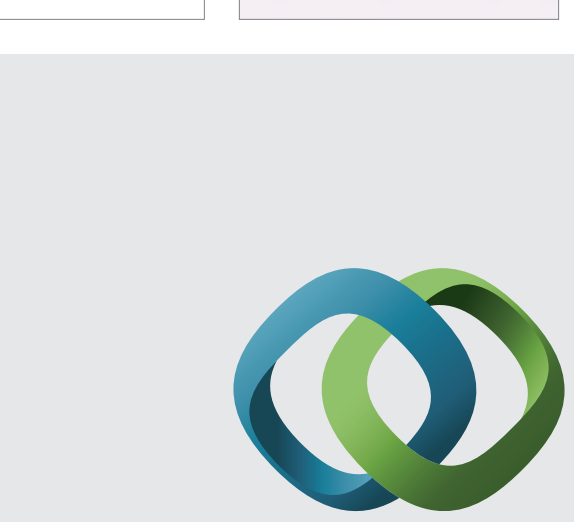

\section{Hindawi}

Submit your manuscripts at

http://www.hindawi.com
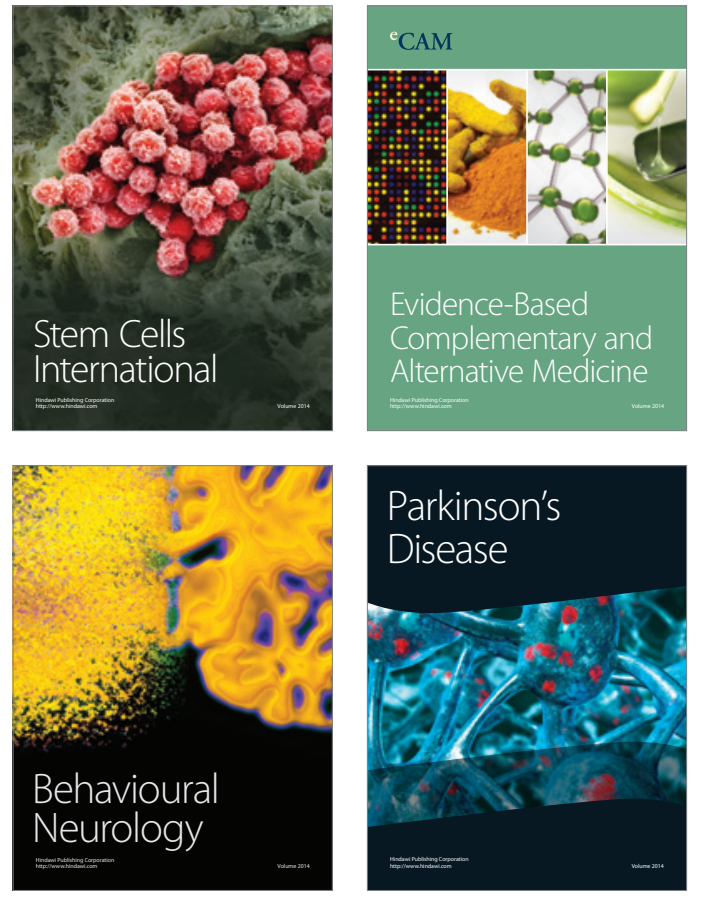
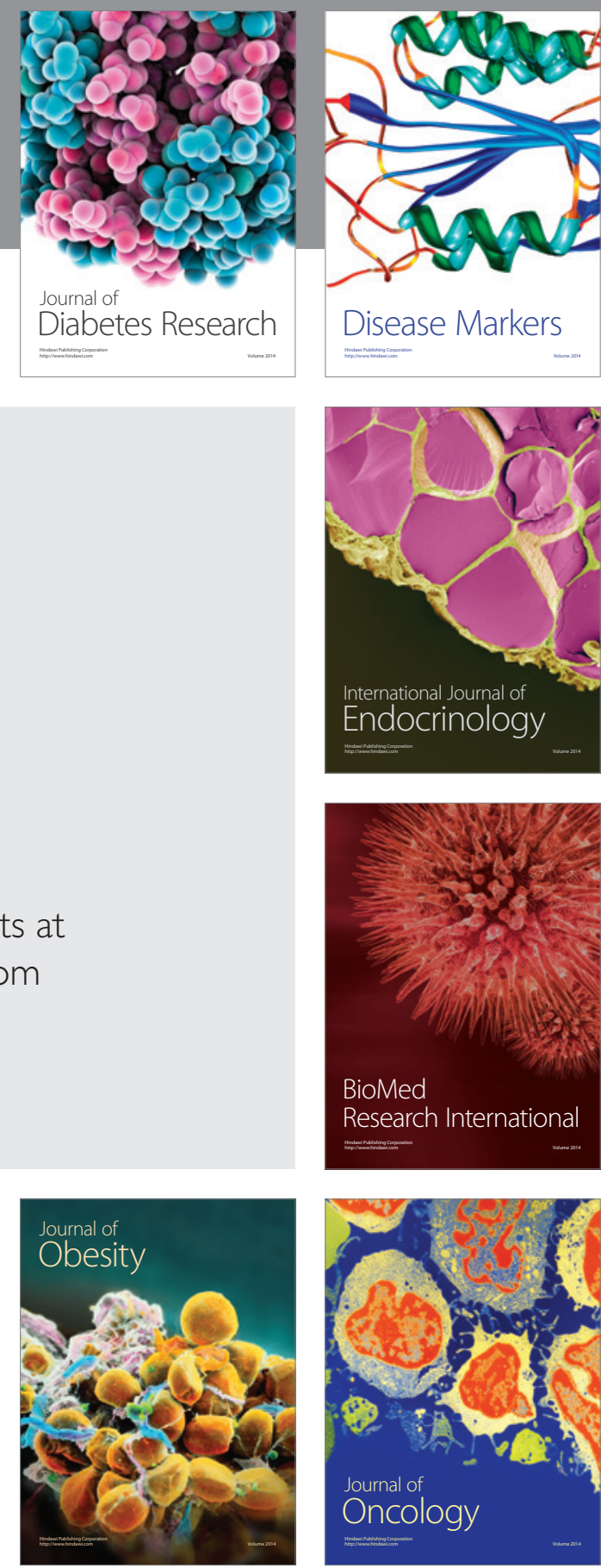

Disease Markers
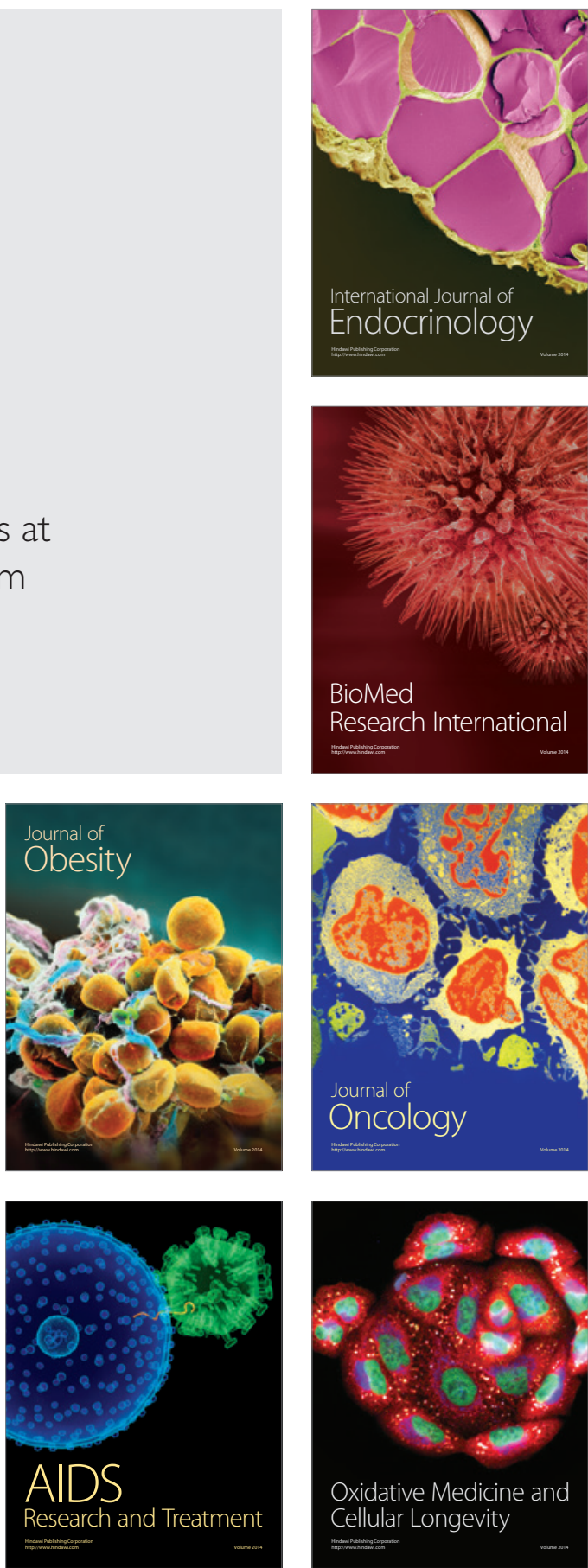